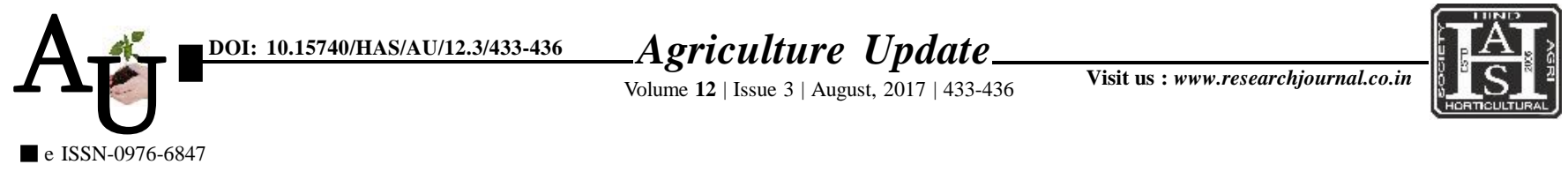

\title{
Research Article: Front line demonstration on improved cultivation practices in tomato (Trellising, drip irrigation and mulching)
}

\author{
GAYATHRI KARIPE AND K. KRISHNAVENI
}

Article Chronicle:

Received :

11.05.2017;

Revised :

29.06.2017;

Accepted :

11.07.2017

KeY Words:

Improved practices in tomato, Farmers practice, Fruit rot control, Yield of tomatoes/ha, Economics
SUMMARY : Front-line demonstrations on improved cultivation practices in tomato were conducted under the close supervision of scientists of the Krishi Vigyan Kendra, Adilabad district. Front-line demonstrations (FLDs) are the technologies demonstrated for the first time by the scientists themselves before being fed into the main extension system of the State Department of Agriculture. Front-Line Demonstrations are conducted under the close supervision of the scientists of the National Agriculture Research System comprising of ICAR Institute, National Research Centres, Project Directorates, Krishi Vigyan Kendras and the State Agricultural Universities and its regional Research Stations. This FLD conducted for two years during Kharif to Rabi 2012 and Kharif to Rabi 2013 at 10 locations from four villages. The comparison was made between farmers regular practice (Furrow method of irrigation, not following trellising and mulching) and improved practice (Trellising, Plastic mulching, Drip irrigation). This production system keeps plants growing upright and off the ground. Most growers who have tried it are convinced the fruit quality is better (bigger fruit, less rots, easier to pick). In Kharif, 2013 average yield obtained in demo is $1019 \mathrm{q} / \mathrm{ha}$, in farmers practice $438 \mathrm{q} / \mathrm{ha}$. The percentage increase in demo yield is 133 per cent over farmers practice. The benefit cost ratio is also high in demo is 3.07 , low in check is 1.4. In Kharif, 2012 demo yield is almost double i.e., $880 \mathrm{q} / \mathrm{ha}$ with compare to farmers practice is $430 \mathrm{q} / \mathrm{ha}$. In demo plot the yield, fruit size improved. Quality of fruits improved by complete controlling of fruit rot disease attack.

How to cite this article : Karipe, Gayathri and Krishnaveni, K. (2017). Front line demonstration on improved cultivation practices in tomato (Trellising, drip irrigation and mulching). Agric. Update, 12(3): 433-436; DOI : 10.15740/HAS/AU/12.3/433-436.
Author for correspondence :

\section{GAYATHRI KARIPE}

DDS Krishi Vigyan

Kendra, Zaheerabad,

MEDAK (TELANGANA)

INDIA

See end of the article for

authors' affiliations 